\title{
International Congresses, Conferences, Symposia, Meetings, and Seminars in the Field of Chemical Sciences held all over the world in $\mathbf{2 0 1 5}$
}

July 5-10

Bordeaux, France

July $12-15$

Utrecht, Netherlands

July $14-16$

North Bethesda, USA

July 20-22

Edinburgh, UK

July 20-23

Cambridge, UK

July 22-25

Boston, USA

August 9-14

Busan, Korea

August 23-28

Santa Barbara, UK

August 30-September 4 Kazan'

September 9-12

Plyos

September 13-17

Beaune, France

September 13-18

Wrociaw, Poland

September 14-19

Zelenogradsk town,

Kaliningrad Region

September 20-25

Moscow Region,

Soyuz resort

September $21-25$

Plyos

October $18-21$

Jeju island, Korea 22nd International Symposium on Ionic Polymerization (IP-2015)

ip15.sciencesconf.org

17th International Symposium on Relations between Homogeneous and Heterogeneous Catalysis (ISHHC17)

www.ishhc17.org

19th Annual Green Chemistry \& Engineering Conference

www.gcande.org

1st Chemistry in Energy Conference (1st CEC)

http://www.maggichurchouseevents.co.uk/cec/

Synthesis in Organic Chemistry

http://www.rsc.org/ConferencesAndEvents/RSCConferences/Organic_Synthesis_24/

Drug Discovery \& Therapy World Congress 2015

http://drug-discovery-conference.us/

45th IUPAC World Chemistry Congress

www.iupac2015.org

International Society of Heterocyclic Chemistry Congress

www.ishc-web.org

XII European Congress on Catalysis "Catalysis:

Balancing the Use of Fossil and Renewable Resources"

http://www.europacat2015.com/

All-Russian Scientific and Practical Conference with International Participation and School for Young Scientists "Production and Modification of Synthetic Fibers for Innovative Materials, Composites, and Goods"

(Fibers and Composites-2015»)

http://conf.scftec.ru

6th EuCheMS Conference on Nitrogen Ligands

www.nligands2015.com

XXI International Conference on Horizons in Hydrogen Bond Research https://hbond2015.chem.uni.wroc.pl/

VIII Scientific and Engineering Conference with International Participation "Supercritical Fluids: Fundamentals, Technologies, Innovations" and All-Russian School Conference for Young Scientists "Supercritical Fluid Technologies and Solution of Environmental Problems" http://conf.scftec.ru

Second International Fall School on Organic Electronics ISFOE-2015 www.ispm.ru/isfoe

VII All-Russian Scientific Conference with International Participation "Modern Methods of Theoretical and Experimental Electrochemistry" http://elchem.isc-ras.ru/

10th International Medicinal Chemistry Symposium AIMECS15 http://www.aimecs2015.org 